\title{
Provocări tehnologice în crearea standardelor pentru analiza amprentelor digitale
}

\section{Technological Challenges in Creating Standards for Fingerprint Analysis}

\section{Ancuţa Elena Franț ${ }^{1}$}

Rezumat: Este cunoscut faptul că analiza amprentelor este o metodă care poate duce la identificarea corectă a unei persoane. Este mai puţin cunoscut faptul că acurateţea acestei metode este pusă în pericol, atunci când se utilizează tehnologia digitală pentru a stoca şi a compara informaţii cu privire la amprente. Utilizarea tehnologiei în analiza amprentelor este foarte importantă, deoarece permite diverse activităţi care sunt vitale pentru o anchetă penală, de exemplu comparaţia între o anumită amprentă, găsită la locul crimei, şi amprentele stocate în baze de date. $\mathrm{Cu}$ toate acestea, stocarea amprentelor prin utilizarea inteligenţei artificiale nu este o sarcină simplă, deoarece informaţiile trebuie protejate de potenţiale ameninţări. O modalitate simplă de a proteja informaţiile referitoare la amprente este de a cripta informaţiile, dar aceasta înseamnă că, atunci când informaţiile sunt transferate, receptorul trebuie să aibă cheia corespunzătoare pentru a decripta informaţiile. Acest lucru duce la necesitatea unui algoritm standard, care trebuie utilizat atât de expeditor, cât şi de receptor. Această lucrare analizează provocările creării unui astfel de algoritm standard şi evaluează implicaţiile standardizării în ceea ce priveşte utilizarea amprentelor în identificarea criminalistică.

Cuvinte-cheie: amprentă digitală; standardizare; investigație penală; algoritm

\begin{abstract}
It is widely known that the analysis of fingerprints is a method which can lead to the correct identification of a person. It is lesser known that the accuracy of this method is endangered, when it comes to using digital technology, in order to store and compare information regarding fingerprints. The use of digital technology in analysing fingerprints is very important, because it enables various activities which are vital for a criminal investigation, for example the comparison between a certain fingerprint, found at crime scene, with the fingerprints which are stored in databases. However, storing fingerprints in a digital form is not a simple task, as the information must be protected from potential threats. A simple way to protect the information regarding fingerprints is to encrypt the information, but this means that, when information is transferred, the receptor must have the appropriate key, in order to decrypt the information. This leads to the necessity of a standard algorithm, which must be used by both the sender and the receiver. This paper
\end{abstract}

\footnotetext{
${ }^{1}$ Lector univ. dr., Facultatea de Drept, Universitatea „Alexandru Ioan Cuza” din Iași, email: ancuta.frant@uaic.ro.
} 
analyses the challenges of creating such a standard algorithm and assesses the implications of standardization in fingerprinting.

Keywords: fingerprint; standardization; criminal investigation; algorithm

\section{Importanţa tehnologiei în utilizarea amprentelor digitale}

Folosirea amprentele digitale este, în esenţă, o latură a biometriei, care reprezintă ştiinţa identificării indivizilor pe baza caracteristicilor biologice 2 . Parametrii biometrici care pot fi utilizaţi pentru identificare sunt multipli şi includ: amprentele digitale, geometria mâinii, reţeaua vaselor de sânge subcutanate, trăsăturile feţei, irisul, amprenta vocală ${ }^{3}$.

Analiza amprentelor digitale reprezintă o metodă de identificare criminalistică de mare acurateţe. Utilizarea analizei amprentelor nu se limitează, însă doar la domeniul investigaţiilor penale. Fiind o metodă de identificare a persoanelor, amprentele prezintă potenţial de utilizare în orice domeniu în care este necesară autentificarea indivizilor, de exemplu pentru a accesa un computer, telefonul mobil, un automat bancar, maşina sau chiar casa. Practic, utilizarea amprentelor asigură o securitate sporită, permiţând doar persoanelor autorizate să aibă acces în diferite situaţii, dintre care cele mai frecvente se referă la utilizarea anumitor bunuri. În demersul de utilizare a amprentelor digitale în diferite domenii, multe dintre ele de natură comercială, este absolut necesară folosirea tehnologiei ${ }^{4}$.

În ceea ce priveşte analiza amprentelor în scopul identificării criminalistice, tehnologia permite stocarea unui număr foarte mare de amprente şi compararea relativ rapidă a unei amprente găsită la faţa locului cu amprentele din bazele de bate. De asemenea, tehnologia permite desfăşurarea cu succes a cooperării între organele de poliţie, la nivel naţional şi internaţional, în scopul asigurării operativităţii în acţiunile de combatere şi prevenire a criminalităţii naţionale şi internaţionale. Un exemplu de utilizare cu succes a tehnologiei pentru folosirea amprentelor în anchetele penale îl reprezintă programele de tip AFIS ${ }^{5}$. Practic, fără utilizarea tehnologiei, analiza amprentelor în scop criminalistic s-ar face cu mare dificultate, mai ales în contextul actual al dezvoltării la scară foarte largă a criminalităţii transfrontaliere; aceasta ar umbri potenţialul extraordinar de identificare pe care îl prezintă amprentele digitale.

2 A. Jain, R. Bolle, S. Pankanti, Introduction to Biometrics, în A. Jain, Bolle R., Pankanti S. (editori), Biometrics, Springer, Boston, MA, 1996, pp. 1-41, [Online] la https://doi.org/10.1007/0-306-47044-6_1, accesat 17.11.2021.

${ }^{3}$ T. Frater, Standards for Fingerprint Identification, [Online] la http://www.sis.pitt.edu/ mbsclass/standards/frater/intro.htm, accesat 3.12.2021.

${ }^{4}$ Pentru detalii, a se vedea L. O'Gorman, An overview of fingerprint verification technologies, în Information Security Technical Report, Vol. 3, Nr. 1/1998, pp. 21-32, [Online] la https://doi.org/10.1016/S1363-4127(98)80015-0, accesat 17.11.2021.

${ }^{5}$ Pentru detalii, a se vedea A. Jain, S. Pankanti, Automated Fingerprint Identification and Imaging Systems, în H. C. Lee, R. E. Gaensslen (editori), Advances in Fingerprint Technology, second edition, CRC Press, Boca Raton, 2001, pp. 285-336. 
În privinţa utilizării amprentelor în scopul permiterii accesului la anumite bunuri sau servicii, tehnologia este, de asemenea, indispensabilă. Autentificarea trebuie să se facă rapid şi fără asistenţa unei persoane de specialitate, în situaţii dintre cele mai diverse. Este suficient să ne gândim doar la utilizarea amprentei pentru permiterea accesului la propriul telefon mobil, pentru a înţelege că folosirea amprentelor în scopul autentificării nu ar fi posibilă în absenţa unei tehnologii care să permită recunoaşterea aproape imediată a caracteristicilor biometrice. În afara avantajului rapidităţii, utilizarea tehnologiei prezintă şi avantajul acurateței. Identificarea după amprente presupune, teoretic, găsirea identităţii între trăsăturile comparate, respectiv evidenţierea situaţiilor în care nu există identitate ${ }^{6}$. Pentru aceasta, trebuie comparate detalii de mare finețe, iar această operaţiune se poate face în mod riguros şi rapid cu ajutorul tehnologiei.

În prezent, există un interes crescând pentru aspectele referitoare la utilizarea biometriei, în special deoarece oamenii observă avantajele pe care utilizarea caracteristicilor biometrice le poate avea. De asemenea, interesul este generat şi de alţi factori, precum scăderea preţului senzorilor şi îmbunătăţirea tehnologiei utilizate. În paralel, se constată o creştere a conştientizării la scară largă a necesităţii de a evidenţia punctele tari şi punctele slabe ale demersului de utilizare a tehnologiei pentru identificarea sau autentificarea cu ajutorul elementelor biometrice $^{7}$. Avantajele utilizării biometriei prin intermediul tehnologiei sunt evidente, dar nu trebuie să pierdem din vedere faptul că o simplă eroare în funcţionarea tehnologiei ne poate face extrem de vulnerabili şi poate compromite siguranţa la care aspirăm tocmai prin utilizarea tehnologiei în analiza parametrilor biometrici.

Amprentele digitale reprezintă prima categorie de parametri biometrici pentru analiza cărora s-a folosit tehnologia computerizată. La începutul anilor '60 ai secolului XX, crearea componentelor de hardware capabile să proceseze suficient de bine imaginea amprentelor a făcut posibilă analiza computerizată a amprentelor. În anii ' 80 ai secolului XX, dezvoltarea tehnologiei calculatoarelor personale şi dezvoltarea scannerelor optice au permis utilizarea identificării prin amprente şi în alte domenii decât cel al investigaţiilor penale. Procentul mare de utilizare a amprentelor digitale pentru identificare şi autentificare este dat de faptul că metoda este relativ uşor de folosit, este relativ ieftină şi prezintă grad mare de acurateţe, atât în investigaţiile penale, cât şi în asigurarea securităţii în diferite activităţi cotidiene. În plus, metoda nu este invazivă ${ }^{8}$.

${ }^{6}$ Vom vedea, mai jos, că prin utilizarea tehnologiei în analiza amprentelor este dificil de obținut concluzia identității, la modul absolut.

${ }^{7}$ A. Jain et al., Introduction to Biometrics, op. cit.

${ }^{8}$ L. O'Gorman, Fingerprint Verification, în A. Jain, R. Bolle, S. Pankanti (editori), Biometrics. Personal Identification in Networked Society, Springer, Boston, MA, 1996, pp. 43-44, [Online] la https://doi.org/10.1007/0-306-47044-6_2, accesat 17.11.2021; T. Frater, op. cit. 


\section{Scurt istoric al utilizării amprentelor în identificarea persoanelor}

În demersul nostru de a analiza provocările tehnologice care apar în utilizarea amprentelor digitale, considerăm că este important să realizăm un scurt istoric al utilizării amprentelor ca modalitate de identificare a persoanelor. Motivul este dat de faptul că, dintre toate caracteristicile biometrice, amprentele sunt cele care au fost utilizate pentru cea mai mare perioadă de timp, perioadă în care au demonstrat din plin utilitatea lor.

Dovezile arheologice sugerează că utilizarea amprentelor pentru a identifica o anumită persoană probabil se practica în anii 6000-7000 î.e.n., de exemplu de către asirieni, chinezi şi locuitorii oraşului Ierihon. Unele documente emise în societatea chineză erau sigilate cu un sigiliu din argilă, pe care emitentul îşi lăsa amprenta degetului mare. Pe unele cărămizi ale caselor din Ierihon au fost găsite perechi de amprente ale degetelor mari, aparţinând, probabil, celui care făcuse cărămizile. Unele piese din ceramică datând din acea perioadă conţin amprente. Desigur, în prezent nu putem şti exact care era scopul utilizării amprentelor ${ }^{9}$. Amprentele care, din modul în care au fost poziţionate, arată în mod clar faptul că au fost lăsate intenţionat, cum sunt cele de pe sigilii, ilustrează faptul că era recunoscută valoarea lor identificatoare. În ceea ce priveşte amprentele de pe obiectele create cu ajutorul mâinilor (cum sunt obiectele de ceramică sau cărămizile), acestea, în mod firesc, pot conţine amprente imprimate în timpul procesului de fabricaţie. Astfel de amprente „neintenţionate” pot apărea în locuri diverse şi de multe ori sunt amprente parţiale. Dacă, însă, amprentele de pe astfel de obiecte sunt totale şi se găsesc într-un anumit loc (de exemplu, pe partea bazală a vaselor din ceramică), ele pot ilustra faptul că s-a dorit în mod intenţionat lăsarea amprentei; în astfel de cazuri, amprenta poate fi interpretată ca o veritabilă „semnătură” a meşterului, deci având valoare identificatoare.

În 1686 Marcello Malpighi, profesor de anatomie la Universitatea din Bologna, realizează un studiu asupra desenului de pe degete şi observă faptul că acesta conţine creste, spirale şi curbe. În 1923, Joannes Evangelista Purkinje, profesor de anatomie la Universitatea Breslau, a publicat o lucrare în care descrie nouă tipuri de modele ale amprentelor ${ }^{10}$. Niciunul dintre cei doi oameni de ştiinţă menţionaţi nu a făcut vreo referire la valoarea identificatoare a amprentelor, dar observaţiile lor au încurajat cercetări ulterioare cu privire la amprente, inclusiv cu privire la posibilitatea de a utiliza amprentele pentru a identifica indivizii ${ }^{11}$.

${ }^{9}$ R. Allen, P. Sankar, S. Prabhakar, Fingerprint Identification Technology, în J. Wayman, A. Jain, D. Maltoni, D. Maio (editori), Biometric Systems, Springer, London, 2005, p. 21, [Online] la https://doi.org/10.1007/1-84628-064-8_2, accesat 20.11.2021.

${ }^{10} \mathrm{~J}$. Berry, D. A. Stoney, History and Development of Fingerprinting, în H. C. Lee, R. E. Gaensslen (editori), Advances in Fingerprint Technology, second edition, CRC Press, Boca Raton, 2001, p. 32.

${ }^{11}$ R. Allen et al., op. cit., p. 21. 
Un moment de cotitură în privinţa utilizării amprentelor pentru identificare este reprezentat de descoperirea pe care a făcut-o Sir William Herschel. Acesta a fost un magistrat britanic, care, în timpul activităţii sale din Jungipoor, India, a utilizat, pentru identificarea persoanelor care erau părţi în diferite contracte, impresiunile întregii fețe palmare a mâinilor acestora. Se pare că metoda, utilizată începând cu 1856, a fost inspirată de superstiţiile populaţiei indigene. Analizând impresiunile mâinilor de la un număr mare de persoane, Herschel a realizat faptul că amprentele degetelor nu se repetau, desprinzând, astfel, concluzia că erau unice. Pentru a demonstra o altă caracteristică a amprentelor, fixitatea, Herschel şi-a monitorizat impresiunile propriilor degete, de-a lungul vieţii ${ }^{12}$.

În anii '70 ai secolului XIX, Dr. Henry Faulds, un chirurg britanic ce activa în Japonia, a descoperit urme de degete pe ceramică veche şi, studiind aceste amprente, a conştientizat potenţialul lor în identificarea persoanelor. Faulds a dezvoltat o metodă de a clasifica modelele formate de dispunerea crestelor de degete. În 1880, Faulds a adus la cunoştinţa lui Charles Darwin descoperirile sale cu privire la amprente, iar acesta le-a trimis vărului său, Sir Francis Galton ${ }^{13}$.

În 1892, în urma unui studiu sistematic privind valoarea identificatoare a amprentelor, Sir Francis Galton a publicat prima carte despre potenţialul individualizator al amprentelor, intitulată „Fingerprints”. Galton a adus dovezi ştiinţifice la ceea ce Herschel şi Faulds bănuiseră, şi anume că amprentele sunt unice şi rămân neschimbate de-a lungul vieţii. Calculele lui Galton arătau că probabilitatea ca două amprente să fie identice este de 1 la 64 de miliarde. Sistemul de clasificare a amprentelor dezvoltat de Sir Francis Galton stă la baza sistemului care este folosit pe scară largă şi în prezent ${ }^{14}$.

În 1892, Juan Vucetich, un ofiţer de poliţie din Argentina, a realizat prima identificare a autorului unei crime prin analiza amprentei digitale a acestuia, pe baza urmei unui deget murdar de sânge ${ }^{15}$.

În 1897, Sir Edward Henry, un ofiţer de poliţie britanic din India, pe baza studiilor lui Sir Francis Galton, a realizat un sistem de clasificare a amprentelor care a fost adoptat de Scotland Yard în 1901 şi este în continuare folosit pe scară largă ${ }^{16}$.

În prezentarea momentelor cruciale pentru conştientizarea valorii identificatoare a amprentelor nu putem să nu facem referire şi la activitatea lui Alphonse Bertillon, care a lucrat în cadrul poliţiei din Paris şi care, începând cu anul 1800, a dezvoltat sistemul de antropometrie. Sistemul antropometric presupunea măsurarea a diferiţi parametri corporali (dimensiunea craniului, înălţime, greutate, lungimea braţelor, a picioarelor, a degetului arătător etc.), despre care se credea că, luaţi în considerare în ansamblul lor, aveau potenţial ridicat de individualizare. Bertillon calculase că probabilitatea ca două persoane să prezinte aceleaşi dimensiuni la aceiaşi parametri era de 1 la 4 milioane. Acest sistem a fost

\footnotetext{
12 Ibidem.

${ }^{13}$ Idem, p. 22.

14 Ibidem.

${ }^{15}$ Ibidem.

${ }^{16}$ Ibidem.
} 
folosit la clasificarea persoanelor condamnate şi la identificarea recidiviştilor. Totuşi, sistemul dezvoltat de Alphonse Bertillon s-a dovedit a nu fi atât de precis pe cât se credea. De exemplu, s-a descoperit că doi prizonieri, ambii numiţi William West, aveau aproape aceleaşi dimensiuni ale parametrilor antropometrici ${ }^{17}$. Situaţiile de acest gen, precum şi dificultatea de a folosi sistemul propus de Bertillon, a dus la scăderea treptată a gradului de utilizare a sistemului antropometric de către poliţie. În anul 1915, doar ţara natală a lui Bertillon, Franţa, mai utiliza acest sistem, dar, în cele din urmă, şi Franţa a renunţat la el. Pentru a înlocui sistemul antropometric, au fost căutate metode cu o mai mare acurateţe şi mai uşor de folosit, ceea ce a creat condiţiile pentru folosirea la scară din ce în ce mai mare a sistemului de identificare bazat pe amprente ${ }^{18}$. Oricum, trebuie menţionat faptul că Alphonse Bertillon a adus o contribuţie importantă şi în ceea ce priveşte utilizarea amprentelor, de exemplu observaţia sa că 12-15 puncte coincidente sunt suficiente pentru a desprinde concluzia identităţii ${ }^{19}$.

\section{Tipuri de verificare a amprentelor prin utilizarea tehnologiei}

Identificarea cu ajutorul amprentelor prin utilizarea tehnologiei presupune desfăşurarea anterioară a unei operaţiuni de verificare. Această verificare prezintă o serie de particularităţi, în funcţie de scopul pentru care este utilizată amprenta ${ }^{20}$.

Verificarea efectuată cu scopul de a permite unei persoane accesul la utilizarea unui bun sau la o anumită facilitate se numeşte potrivire unu-la-unu. În acest caz, verificarea presupune compararea unei amprente cu o amprentă care este deja înregistrată în sistem. În vederea verificării, o persoană trebuie, mai întâi, săşi înregistreze amprenta în sistemul care este utilizat. Imaginea acelei amprente înregistrate este stocată în sistem, în format comprimat, iar apoi amprenta utilizatorului este comparată cu acea imagine ${ }^{21}$.

Verificarea efectuată cu scopul identificării criminalistice se numeşte unula-mai-multe. În acest caz, imaginea unei amprente provenind de la o persoană necunoscută este comparată cu imaginile dintr-o bază de date ale amprentelor aparţinând unor persoane cu identitate cunoscută ${ }^{22}$.

Există şi un al treilea tip, informal, de verificare, numit unu-la-câteva, care se aplică în situaţia în care un sistem de acces pe bază de amprentă este utilizat de

${ }^{17}$ Idem, p. 21.

${ }^{18}$ R. B. Fosdick, Passing of the Bertillon System of Identification, în Journal of Criminal Law and Criminology, Vol. 6, Nr. 3/1915, pp. 363-369, [Online] la https://scholarlycommons. law.northwestern.edu/cgi/viewcontent.cgi?article=1374\&context=jclc, accesat 22.11.2021,

${ }^{19}$ A. Bertillon, Notes et observations médico-légales. Les empreintes digitales, în Archives d'anthropologie criminelle de médecine légale et de psychologie normale et pathologique, Vol. 27/1912, p. 52, [Online] la https://criminocorpus.org/ en/ref/114/20706/, accesat 22.11.2021,.

${ }^{20}$ L. O’Gorman, Fingerprint Verification, op. cit., p. 45.

${ }^{21}$ Ibidem.

${ }^{22}$ Ibidem. 
un număr redus de persoane, de exemplu atunci când membrii unei familii folosesc un sistem bazat pe amprente pentru a intra în casă ${ }^{23}$.

\section{Procedura identificării prin analiza amprentei, cu ajutorul tehnologiei}

Primul pas în realizarea identificării cu ajutorul amprentelor, prin utilizarea tehnologiei, este realizarea unei imagini a amprentei. Ulterior, are loc procesarea imaginii, al cărei scop este de a se obţine cea mai bună imagine posibilă, pentru a avea un rezultat corect după verificare ${ }^{24}$.

În esenţă, procedura de identificare cu ajutorul amprentei trebuie să parcurgă următoarele etape: reducerea neclarităţii şi îmbunătăţirea imaginii, detectarea (sau extragerea) caracteristicilor şi verificarea potrivirii. În continuare, vom prezenta detalii privind aceste etape.

\subsection{Reducerea neclarităţii şi îmbunătăţirea imaginii}

Imaginea unei amprente este, de regulă, neclară, în special datorită faptului că degetele sunt de cele mai multe ori acoperite cu diferite substanţe, precum murdărie, transpiraţie, sebum etc. Acest pas urmăreşte, în primul rând, sporirea contrastului dintre creste şi şanţuri. Pentru obţinerea acestui rezultat, se utilizează filtrele adaptive potrivite şi pragurile adaptive ${ }^{25}$.

O trăsătură a desenului papilar care se dovedeşte a fi utilă în procesarea imaginii amprentei este aşa-numita „redundanţă” a crestelor paralele, care poate fi folosită pentru a crea un filtru adaptiv potrivit. Acest filtru se aplică fiecărui pixel al imaginii. Pe baza orientării locale a crestelor în jurul fiecărui pixel, se aplică filtrul adaptiv pentru a evidenţia crestele orientate în aceeaşi direcţie, în acelaşi timp estompând tot ceea ce are o orientare diferită. De exemplu, particulele de murdărie care „îmbâcsesc” amprenta pot uni două creste învecinate, dar aceste particule, fiind perpendiculare pe aceste creste, au o direcţie diferită, deci vor fi identificate drept elemente care nu fac parte din imaginea amprentei propriu-zise. Identificarea se face cu ajutorul filtrului adaptiv, care are în vedere cursul firesc al crestelor $^{26}$.

Ulterior, are loc binarizarea, adică separarea crestelor de fundal. Acest proces facilitează desfăşurarea paşilor următori de analiză a amprentei. Practic, în timpul operaţiunii de binarizare, are loc transformarea unei imagini care, iniţial, este în tonuri de gri, într-o imagine binară. Operaţiunea de binarizare este destul de dificilă, deoarece nu toate imaginile amprentelor au aceleaşi specificaţii privind contrastul, ceea ce înseamnă că nu se poate alege acelaşi prag de intensitate. Mai mult, contrastul poate varia chiar în cadrul aceleiaşi imagini, de exemplu dacă presiunea cu care a fost creată urma de deget a fost mai mare în mijlocul desenului

\footnotetext{
${ }^{23}$ Ibidem.

${ }^{24}$ Ibidem.

${ }^{25}$ Idem, p. 47.

${ }^{26}$ Idem, pp. 47-48.
} 
papilar. Pentru a depăşi această dificultate, este utilizat un procedeu numit prag adaptiv local ${ }^{27}$.

În continuare, are loc procesul de subţiere a crestelor, care reduce grosimea crestelor, chiar până la 1 pixel. Această operaţiune uşurează detectarea unor detalii ale amprentei, precum sfârşitul de creastă şi bifurcaţia ${ }^{28}$.

Procedura de reducere a neclarităţii şi de îmbunătăţire a imaginii necesită un interval de timp destul de îndelungat. Din acest motiv, unele sisteme de analiză a amprentelor sunt create astfel încât să se desfăşoare cât mai repede această etapă, dar o astfel de abordare poate compromite rezultatul final. Desfăşurarea tuturor operaţiunilor subsecvente depinde de calitatea imaginii, aşa cum este ea obţinută în această etapă. Din acest motiv, se recomandă ca sistemele de analiză a amprentelor să nu sacrifice calitatea rezultatului final, de dragul desfăşurării cât mai rapide a procesului de identificare ${ }^{29}$.

\subsection{Detectarea caracteristicilor}

Detectarea caracteristicilor este relativ uşor de realizat, după ce imaginea a fost procesată în etapa anterioară. De regulă, chiar dacă mai există erori, în sensul că apar detalii „false”, ele pot fi detectate prin utilizarea pragurilor determinate empiric. De exemplu, dacă se constată două capetele de crestă care sunt foarte apropiate unul de celălalt, se consideră că acestea fac parte din aceeaşi crestă, iar discontinuitatea a apărut, probabil, datorită unei cicatrici sau datorită faptului că degetul era uscat când a fost creată amprenta. În urma procedeului de detectare a caracteristicilor se obţine minutia template, adică un model al detaliilor şi al locului ocupat de acestea. De regulă, în această etapă sunt detectate 10 până la 100 de detalii, în funcţie de diferiţi factori, de exemplu în funcţie de calitatea imaginii iniţiale ${ }^{30}$.

\subsection{Verificarea potrivirii}

În această etapă are loc compararea amprentei analizate cu o amprentă care este deja înregistrată în sistem. În principiu, verificarea presupune compararea vecinătăţilor detaliilor apropiate, căutându-se indicii de similaritate ${ }^{31}$. Dacă, în urma comparării, apar doar foarte mici diferenţe, atunci concluzia va fi cea de potrivire a vecinătăţilor. Această procedură de comparare se face exhaustiv pentru

${ }^{27}$ Idem, p. 48.

${ }^{28}$ Ibidem.

${ }^{29}$ Ibidem.

${ }^{30}$ Idem, p. 50.

31 Precizăm că am folosit intenționat cuvântul „similaritate” și nu cuvântul „identitate”. Aceasta, deoarece va exista rar o potrivire exactă a vecinătăților, din două motive: neclaritatea amprentei, care provine din faptul că degetul este, de regulă, îmbâcsit cu diverse substanțe; caracteristicile pielii, care este un țesut elastic, ceea ce înseamnă că vor exista frecvent mici variații în aspectul și dispunerea detaliilor. A se vedea L. O’Gorman, Fingerprint Verification, op. cit., p. 50. 
toate combinaţiile de vecinătăţi şi, dacă există suficiente similarităţi, atunci concluzia privind întreaga amprentă va fi de potrivire ${ }^{32}$.

În urma operaţiunii de verificare se formulează o concluzie privind gradul de potrivire, concluzie care, de regulă, se exprimă sub forma unui număr de la 0 la 1 sau de la 10 la 100. Rezultatul obţinut se compară cu un prag predeterminat. Dacă rezultatul este mai mare decât pragul, concluzia generală va fi de potrivire, iar dacă rezultatul este mai mic decât pragul, concluzia va fi de nepotrivire. Dacă pragul este stabilit la o valoare mai mare, atunci va creşte probabilitatea de a obţine potriviri corecte, dar va exista un risc mai mare de a obţine respingeri false. Dacă pragul este stabilit la o valoare mai mică, atunci va scădea riscul de a obţine respingeri false, dar creşte riscul de potriviri false. În cazul sistemelor de verificare a amprentelor pentru uz comercial, valoarea pragului va fi stabilită, de regulă, de către structura care pune sistemul la dispoziţia utilizatorilor ${ }^{33}$.

\section{Particularităţi ale utilizării tehnologiei pentru analiza amprentelor în Criminalistică}

Pentru analiza amprentelor în cadrul unei investigaţii criminalistice, de multe ori trebuie realizată o comparare a unei amprente cu amprentele existente într-o bază de date, care poate conţine câteva zeci de milioane de imagini de amprente. Compararea unei amprente ridicate de la faţa locului cu absolut toate amprentele dintr-o bază de date ar necesita alocarea unui interval foarte mare de timp, ceea ce ar încetini desfăşurarea anchetei. Din acest motiv, utilizarea tehnologiei pentru analiza amprentelor în scop criminalistic presupune, de regulă, două etape. În prima etapă, se stabileşte categoria din care face parte amprenta care urmează a fi analizată. În a doua etapă, se compară detaliile de pe amprenta analizată şi cele de pe amprentele din baza de date care fac parte din aceeaşi categorie cu amprenta analizată ${ }^{34}$.

\section{Concluzii privind provocările tehnologice în crearea standardelor pentru analiza amprentelor digitale}

Aşa cum am văzut în cele expuse mai sus, tehnologia este absolut necesară în demersul de utilizare a amprentelor, atât în scopul identificării în cadrul investigaţiilor penale, cât şi în scopul autentificării pentru permiterea accesului, în diverse situaţii. În acelaşi timp, aspectele prezentate evidenţiază complexitatea tehnologiei utilizate în analiza amprentelor şi vulnerabilităţile care pot apărea. Am arătat că, în urma utilizării tehnologiei pentru identificarea unei persoane cu ajutorul amprentei, maximul care se poate obţine nu este o certitudine a identităţii, ci doar o potrivire optimă, bazată pe o similaritate foarte mare. Am văzut că, pentru

\footnotetext{
${ }^{32}$ L. O’Gorman, Fingerprint Verification, op. cit., pp. 50-51.

${ }^{33}$ Idem, p. 51.

${ }^{34}$ Ibidem.
} 
obţinerea unui răspuns, trebuie setat de către factorul uman un anumit prag, a cărui valoare poate influenţa semnificativ rezultatul.

In acest context, apare ca necesară standardizarea tehnologiei de utilizare a amprentelor, mai ales ţinând cont de faptul că necesitatea verificării amprentelor poate apărea nu doar punctual, într-o situaţie dată, ci în situaţii variate, pe plan naţional şi internaţional.

De exemplu, schimbul de informaţii privind amprentele în cadrul cooperării penale internaţionale trebuie să se bazeze pe o compatibilitate foarte bună a sistemelor tehnologice folosite pentru transmiterea, respectiv receptarea informaţiei. Dacă algoritmii de criptare a informaţiei transmise nu se potrivesc cu algoritmii de decriptare pe care îi deţine receptorul, atunci, practic, nu se poate face transferul de informaţii. Dacă imaginea iniţială a amprentei încărcată în sistem nu este de bună calitate, de asemenea, se poate compromite rezultatul, deci ar fi nevoie şi de un standard al imaginilor încărcate.

Un alt exemplu poate fi dat din domeniul autorizării accesului la utilizarea unui automat bancar (ATM) prin analiza amprentei ${ }^{35}$. În lipsa unui standard, în funcţie de tehnologia utilizată şi în funcţie de pragul de potrivire ales, unele bancomate ar putea să permită rapid accesul, altele ar putea avea o rată mare de falsă respingere, această din urmă situaţie ducând la nemulţumire în rândul utilizatorilor.

Aspectele prezentate ilustrează faptul că este necesar a se crea noi standarde, pe măsură ce creşte gradul de utilizare a tehnologiei pentru analiza amprentelor. Însă este dificil de impus standarde în acest domeniu, cu atât mai mult cu cât unele standarde ar trebui adoptate la nivel internaţional. În crearea standardelor, particularităţile de ordin tehnologic joacă un rol foarte important. De asemenea, scopul pentru care este utilizată o anumită tehnologie de recunoaştere a amprentei are un rol major. În acest context, credem că trebuie acordată atenţie armonizării tuturor elementelor în discuţie, astfel încât identificarea persoanelor prin intermediul amprentelor să aibă o rată cât mai mare de reuşită şi să se elimine neclarităţile care, încă, mai există în acest domeniu.

\section{Referinţe}

Allen R., Sankar P., Prabhakar S., Fingerprint Identification Technology, în Wayman J., Jain A., Maltoni D., Maio D. (editori), Biometric Systems, Springer, London, 2005, pp. 22-61, https://doi.org/10.1007/1-84628-064-8_2

Berry J., Stoney D. A., History and Development of Fingerprinting, în Lee H. C., Gaensslen R. E. (editori), Advances in Fingerprint Technology, second edition, CRC Press, Boca Raton, 2001, pp. 14-53

Bertillon A., Notes et observations médico-légales. Les empreintes digitales, în Archives d'anthropologie criminelle de médecine légale et de psychologie normale et pathologique, Vol. 27/1912, pp. 36-52

35 Pentru detalii, a se vedea T. Sangeetha, M. Kumaraguru, S. Akshay, M. Kanishka, Biometric Based Fingerprint Verification System for ATM Machines, în Journal of Physics: Conference Series, 1916, 2021, 012033, [Online] la https://doi.org/10.1088/17426596/1916/1/012033, accesat 29.11.2021. 
Fosdick R. B., Passing of the Bertillon System of Identification, în Journal of Criminal Law and Criminology, Vol. 6, Nr. 3/1915, pp. 363-369

Frater T., Standards for Fingerprint Indentification, [Online]

Jain A., Bolle R., Pankanti S., Introduction to Biometrics, în Jain A., Bolle R., Pankanti S. (editori), Biometrics, Springer, Boston, MA, 1996, pp. 1-41, https://doi.org/10.1007/0-30647044-6_1

Jain A., Pankanti S, Automated Fingerprint Identification and Imaging Systems, în Lee H. C., Gaensslen R. E. (editori), Advances in Fingerprint Technology, second edition, CRC Press, Boca Raton, 2001, pp. 285-336

O'Gorman L., An overview of fingerprint verification technologies, în Information Security Technical Report, Vol. 3, Nr. 1/1998, pp. 21-32, https://doi.org/10.1016/S13634127(98)80015-0

O’Gorman L., Fingerprint Verification, în Jain A., Bolle R., Pankanti S. (editori), Biometrics. Personal Identification in Networked Society, Springer, Boston, MA, 1996, pp. 43-64, https://doi.org/10.1007/0-306-47044-6_2

Sangeetha T., Kumaraguru M., Akshay S., Kanishka M., Biometric Based Fingerprint Verification System for ATM Machines, în Journal of Physics: Conference Series 1916, 2021, 012033, https://doi.org/10.1088/1742-6596/1916/1/012033 
